\title{
FITNESS YOGA AS MODERN TECHNOLOGY OF SPECIAL HEALTH GROUPS' GIRL STUDENTS' PSYCHO-PHYSICAL CONDITION AND PSYCHO-SOCIAL HEALTH STRENGTHENING
}

\author{
Skurikhina N.V. ${ }^{1}$, Kudryavtsev M.D. ${ }^{1,2}$, Kuzmin V.A. ${ }^{1,2}$, Iermakov S. S. ${ }^{3}$ \\ ${ }^{1}$ Siberian Federal University, Russia \\ ${ }^{2}$ Siberian State Aerospace University, Russia \\ ${ }^{3}$ Belgorod National Research University, Russia
}

\begin{abstract}
Purpose: substantiation of purposefulness of fitness yoga application for strengthening of special health groups' girl students' psycho-physical condition and psycho-social health at physical culture training and recreation classes. Material: trainings were practiced twice a week in 2 groups with 20 girl students in every group. Each training session lasted 60 minutes. The following indicators were registered: pressing ups in lying position; torso bending during $30 \mathrm{sec}$. from lying on back position; rising legs up to 90 degrees angle in hanging position; long jump from the spot; forward torso bending; test for coordination. Health condition was determined by express assessment of physical health. Results: in both groups girl students' backbone mobility increased ( $<<0 / 05)$. First group's girl students demonstrated higher results in pressing ups in lying position during 30 sec. (by $7.34+1.2$ times) and in long jump from the spot $(14.2+0.4 \mathrm{~cm})$. It was noticed that fitness yoga exercises render positive influence on girl students' psycho-emotional state, general physical self-feeling and physical condition. Conclusions: targeted fitness yoga exercises' influences on girl-students' organism are recommended for support and correction of their health.
\end{abstract}

Key words: health; life style; fitness yoga; girl students; special health group.

\section{Introduction}

Recent years highly stress social-economic factors; ecological conditions and life style in modern society have been conditioning progressing reduction of population's psycho-physical state and psycho-social health [7]. In Russian Federation subjects work on formation of Russian Federation citizens' healthy life style is continuing (State report on health condition, 2015). In perfection of students' physical fitness main role is played by discipline "Physical culture". Clear methods and means, which, being combined, are perfectly integrated in well organized and adjusted methodic of students' teaching and education, shall be in the base of its teaching [28]. Especially actual is, now, search of most adequate ways and methods of strengthening of population's psychophysical state, as well as development of health related technologies, ensuring formation of personalities' settings for healthy life style [4, 19, 34].

Statistical data say that recent time still more students have counter indications for physical culture practicing in general groups. The problem of physical culture practicing and physical training of special health groups' girl students is now of nationwide, political and scientific significance. Demand in search of new methods of health related correction work was dictated by quantity of $1^{\text {st }}$ year students, sent to special health groups by their health condition [17]. In HEEs special attention is paid to choosing effective correction means and methods for students, who have functional disorders in organism [6]. Such means are static, dynamic and breathing Hatha yoga exercises. The purposefulness of Hatha yoga exercises' application in health related trainings is proved in a number of scientific works $[15,16]$. Besides, positive influence of Hatha yoga on cardio-vascular system, respiratory regulation and skeletal muscular apparatus was found [1,3,14, and 31].

In the course of our research a number of contradictions were found:

- On the one hand, in rapidly changing world there is high demand in highly qualified specialists with excellent health. On the other hand: in educational establishments there are no technologies for reduction of quantity of students with health disorders;

- Theoretical researches in field of health related technologies and their insufficient usage in students' physical education;

- On the one hand: it is necessary to increase motivation for healthy life style (HLS) and for physical

(c) Skurikhina N.V., Kudryavtsev M.D., Kuzmin V.A., lermakov S. S., 2016

doi:10.15561/20755279.2016.0204 
culture practicing of special health groups' girl students. On the on the other hand: absence of methodic recommendations on increasing of motivation.

These contradictions determined the problem of our research. The problem is to search ways for strengthening of special health group girls students' psycho-physical state and psycho-social health; increase of their motivation for healthy life style and physical culture practicing. The basis of such approach is implementation of specially worked out fitness yoga program, developed on the base of physical part of Hatha yoga. Modern fitness yoga combines movements and stability, balance and coordination, concentration and relaxation. It facilitates shaping of stronger, more flexible and e easily controlled body. Such organism is able to resist traumas and over-fatigue [9]. Conception and methods of modern fitness yoga are based on kinetics and physiology. The program of modern fitness yoga is focused on body work as a single unit.

\section{Purpose, tasks of the work, material and methods}

The purpose of the research is substantiation of purposefulness of fitness yoga application for strengthening of special health groups' girl students' psycho-physical condition and psycho-social health at physical culture training and recreation classes.

In the process of the research the following tasks were formulated:

1. To study experience of fitness yoga application as modern technology of strengthening of special health group girl students' psycho-physical state and psycho-social health and formation of life style;

2. to research girl students' motivation for physical culture practicing;

3. To substantiate purposefulness of fitness yoga application as one of effective girl students' health strengthening means at training and recreation physical culture classes;

4. To work out technology of fitness yoga and assess its effectiveness.

Material and methods of the research: fitness yoga exercises were applied in work with special health group girl students in recreational trainings. The trainings were practiced twice a week in 2 groups with 20 girl students in every group. Each training session lasted 60 minutes. One group was trained in gym of institute. Other group was trained in gym of students' hostel. Testing was conducted at the beginning (October) of academic years and at the end (April). Comparative analysis of these trainings' effectiveness showed level of motor qualities and health condition of the trainees.

Experimental program of fitness yoga implied the following: in both groups trainings were conducted as per specially worked out program - fitness yoga. This program permits for girls students with different diseases to train in one and the same time in one health related session.

Experimental program of fitness yoga is a complex training program. It combines movements and stability; balance and coordination; concentration and relaxation. Exercises are oriented on shaping body as strong and flexible, easily controlled and able to resist traumas and excessive fatigue. This program is oriented on simultaneous development of these components. The program implies work on training strength, endurance and flexibility. Sequence of movements is planned in contrast to stresses and for widening of strength and dexterity practical usage in everyday life. The program combines body and mind and is oriented on quick usage of strength, flexibility and stability in real life.

The purpose of the program is mixed work. The basis of the program is modules (dynamic warming up, module "flexibility", module "coordination", module of strength and module of coordination and relaxation module). Depending on task, instructor chooses required module for building training program. In our experiment trainings were conducted by two instructors. We used general program. Every instructor chose modules independently. Intensity was controlled by increasing or reducing of rate within one module. Independent on girl students' fitness and instructor's qualification the program solves important task: teaching of girl students to independent fulfillment of module. In such exercises tension of one muscles group causes stretching of other muscles.

As indicators of physical fitness we used: pressing ups in lying position, torso bending during 30 seconds from lying on back position; rising legs up to 90 degrees angle in hanging position; long jump from the spot; forward bending; test for coordination. Health condition was assessed with "express assessment of physical health" by G.A. Apanasenko. 


\section{Results of the research}

The received results permitted to find influence of the worked out technology and determine peculiarities of its health related impact on girl students' physical condition. It should be noted that this methodic influenced practically equally on speed power qualities. Strengthening of abdomen muscles was proved by: increasing of torso bending by $4.52 \pm 3.1$ in first group and by $4.2 \pm 0.82$ times in second group; rising legs in hanging position increased by $4.6 \pm 0.6$ times in first group and by $4.8 \pm 0.82$ times in second group $(\mathrm{p}<0.05)$.

In both groups the tested increased backbone mobility. It was demonstrated by statistically confident $(p<0.05)$ increase of torso bending by $4.5 \mathrm{~cm}$. Trainees of the first group demonstrated higher results in pressing ups in lying position during 30 seconds (by 7.34 \pm 1.2 times) and in long jump from the spot (by $14.2 \pm 0.4 \mathrm{~cm}$ ). By these indicators confident differences were found $(\mathrm{p}<0.05)$. Health condition of girl students confidently improved $(\mathrm{p}<0.05)[30]$.

The received results permitted to determine influence of the program and find specific features of its health related impact on students' physical condition. It should be noted that this methodic practically equally influenced on speed-power qualities of torso front muscles. Psycho-physical recreation implies practicing of easy and not regulated physical exercises, oriented on restoration of strength and improvement of health [27].

The results are given in diagram (see fig. 1). They permitted to determine health related trainings' influence on girl students' physical condition. Quantity of pressing ups in lying position increased by 3.5 times. Indicator of abdomen muscles' strength increased by 9.75 times; rising legs (up to 90 degrees angle) - up to 4.5 times. It permitted to conclude that fitness yoga program influence positively on speed-power qualities of special health group's girl students.

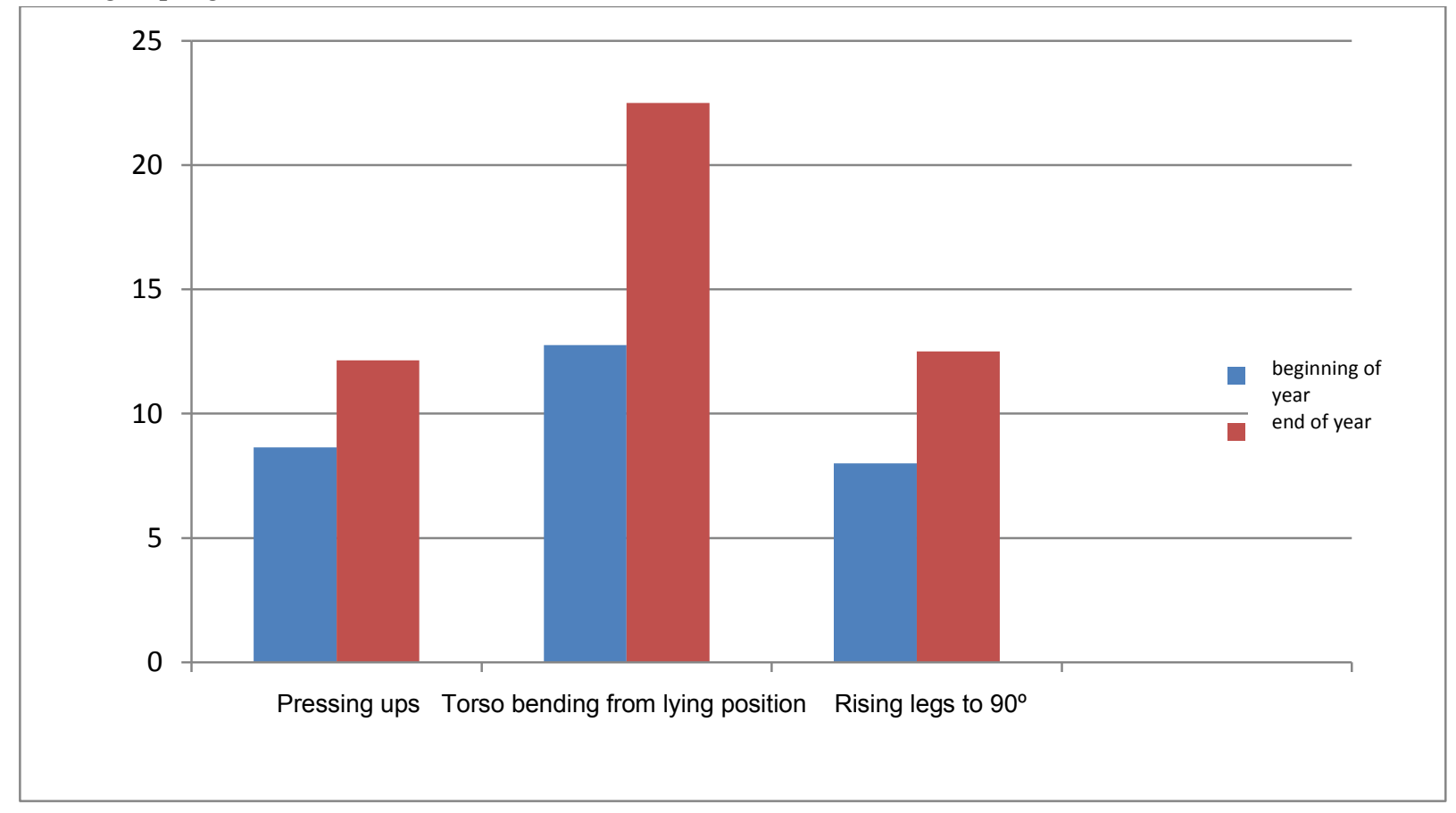

Tests

Fig.1. Mean indicators of girl students' speed-power qualities at the beginning and at the end of academic year

Besides, in both groups mobility of backbone increased (test for flexibility). It reflected in statistically confident increase of torso bending, in average by $3.5 \mathrm{~cm}$.

One of main factors of significance of the offered psycho-physical recreation program is its effectiveness. It is witnessed by reduction of psycho-emotional tension, increase of adaptation to social environment [24]. 


\section{Discussion}

As on to day nobody challenges the opinion of Rejeski W.J. [34], that physical functioning, physical exercises can improve somatic and psychic health. Only recent years, principally new approach to physical fitness problem as one of the most important components of psycho-social health, has been formed $[2,35]$.

Main directions of researches in the frames of the mentioned problem can be systemized in the following way [10]:

- Study of different types and intensity physical exercises' influence on psychic state (anxiety, depression) and their health improvement effect;

- Psychological and physiological mechanisms of physical exercises' influence on psychic health;

- Physical exercises' influence on personality's characteristics of trainees, their mood and psycho-social behavior.

From our point of view the following key moments are very important:

- Kind and intensity of physical load;

- Motivation for practicing of physical culture;

- Meditations and relaxation exercises as mean of psychic health strengthening and psychic tension release $[11,15,21,22,33$, and 36].

It should be noted that recommendations on usage of physical exercises for physical fitness improvement and psychic health strengthening differ significantly. In opinion of Bergera B.G. and Owen D.R. [22] main characteristics of physical exercises with maximal positive effect on psych are the following:

- Aerobic exercises with rhythmic, abdomen type of breathing;

- Absence of competition elements in system of exercises;

- Exercises, definitely determined by space and time characteristics;

- Moderate intensity of exercises;

- Duration of exercises not more than 20-30 min.;

- Regular exercises' practicing as per weekly schedule;

- Exercises, bringing enjoy.

Other researches open possibilities of Hatha yoga application for the following: correction of muscles' and joints' functional disorders in women [8]; increase of workability in students' learning process and in work[12]; perfection of girl students' muscular skeletal apparatus and improvement of individual functional reactions and psycho-physical condition of their organism [29]; prophylaxis of carriage disorders and stretching exercises for schoolchildren [18]; improvement of basketball players' physical fitness indicators [5]; sportsmen's personal psycho-physiological regulation before starts [20]. The results, received by us, supplement the mentioned researches.

One of directions of special health group girl students' health improvement can be combining of exercises for actualization, differentiation, correction and control over somatic and psychic structures. In this case meditative technologies are effective mean of main physiological systems' and parameters of organism current regulation. It permits to recommend them for usage in physical culture classes with special health groups' girl students. It was found that they facilitate restoration of functional bio-symmetry, harmony of life activity, organism's rejuvenation [23].

Hatha yoga asanas were taken as the basis of our experimental fitness yoga program for special health group's girl students. The novelty is that our fitness yoga program is divided into modules (dynamic warming up, modules of flexibility, strength, coordination, relaxation). All asanas in separate module smoothly pass one to the other. They are a single unit. Instructor can compose program of training depending on task. He can change intensity, varying quickness and quantity of modules' repetitions. Thus, girl students with different diseases and physical fitness can be trained in one group and choose quickness of modules' fulfillment and quantity of their repetitions by their own.

The worked out special fitness yoga program can be used in the following way:

- As health related technology in educational process [16];

- For strengthening of psycho-physical condition and psycho-social health of girl students; 


\section{Conclusions}

- For increasing of motivation for physical culture practicing and formation of girl students' healthy life style $[10,25]$.

1. Fitness yoga is one of modern technologies of special health group girl students' psycho-physical condition and psycho-social health strengthening.

2. It is necessary to recommend girl students the steps to optimal health preservation: keep positive mood; choose correctly social medium; control system of personal values; enrich practical philosophy of health with ideas of reflexive pedagogic; to pay equal attention to body and mind [26].

3. The fulfilled by us research permitted to determine positive influence of the worked out fitness yoga program and to find specific features of its impact on girl students' physical condition.

4. Results of the conducted researches supplement theory and methodic of special health group girl students' physical education with new ideas about upgrading of physical education process. The basis of this process is implementation of specially worked out fitness yoga program as effective practice in healthy life style formation.

\section{Conflict of interests}

The authors declare that there is no conflict of interests.

\section{References:}

1. Belikova ZhA, Kondakov VL. Primenenie gimnasticheskikh uprazhnenij khatkha-jogi s cel'iu korrekcii funkcional'nykh narushenij pozvonochnika u studentov special'nykh medicinskikh grupp [Application of Hatha yoga gymnastic exercises for correction of backbone functional disorders in special health group students]. Kul'tura fizicheskaia i zdorov'e, 2012;3:93-101. (in Russian)

2. Belov VN. Psikhologiia zdorov'ia [Psychology of health], Sankt Petersburg; 1994. (in Russian)

3. Bernard T. Khatkha-joga [Hatha yoga], Moscow: Avenue; 2005. (in Russian)

4. Blejer SN. Fizicheskaia aktivnost' - vazhnyj faktor zdorov'ia i funkcional'nogo sostoianiia [Physical functioning as important factor of health and functional state]. Nauchnaia konferenciia "Sovremennye dostizheniia sportivnoj nauki" [Scientific conference "Modern achievements of sports science], Sankt Petersburg; 1994. P. 117-119. (in Russian)

5. Brynzak SS, Burko SV. Improving athletic performance of basketball student team with the classical yoga exercises. Pedagogics, psychology, medical-biological problems of physical training and sports, 2013;10:36. http://dx.doi.org/10.6084/m9.figshare.775314

6. Bulatova GA, Gimazov RM, Bybyk I. Problema poiska racional'nykh podkhodov v fizicheskom vospitanii i ozdorovlenii studentov special'nykh medicinskikh grupp [Problem of rational approaches to special health group students' physical education and health improvement]. Teoriia i praktika fizicheskoj kul'tury $v$ usloviiakh modernizacii obrazovaniia, 2004;1:23-25. (in Russian)

7. Vasil'ev VN. Zdorov'e i stress [Health and stress], Moscow: Knowledge; 1991. (in Russian)

8. Gulbany RSh, Taran AA. Primenenie sistemy jogi v fizicheskoj reabilitacii sustavnoj i myshechnoj gibkosti $\mathrm{u}$ zhenshchin 35-45 let [Application of yoga in physical rehabilitation joint and muscle flexibility in women]. Physical Education of Students, 2011;3:35-45.

9. Diukov VM, Skurikhina NV. Individual'noe zdorov'e cheloveka [Individual health of man], LAP LAMBERT Academic Publishing; 2012. (in Russian)

10. Diukov VM, Skurikhina N V. VUZ zdorovogo obraza zhizni [HEE of healthy life style], LAP LAMBERT Academic Publishing; 2013. (in Russian)

11. Kabachkov VA, Rodionov AV. Psikhologo-pedagogicheskie metody korrekcii deviantnogo poveleniia detej i podrostkov v processe dvigatel'noj aktivnosti [Psychological-pedagogic correction methods of children's and adolescents' deviant behavior in motor functioning]. Mezhdunarodnaia konferenciia "Novye podkhody $k$ psikhoreguliacii $v$ sporte" [International conference "New approaches to psycho-regulation in sports"], Moscow; 1994. P. 37. (in Russian)

12. Yasko GV, Kashuba EV. Innovacii sportivno-ozdorovitel'noj sfery v vuzakh ekonomicheskoj napravlennosti [Innovation sports and health areas in universities supporting basis orientation]. Physical Education of Students, 2011;3:116-118. 
13. Koncepciia federal'noj celevoj programmy "Razvitie fizicheskoj kul'tury i sporta v Rossijskoj Federacii na 2016 - 2020 gody" [Conception of Federal targeted program "Development of physical culture and sports in Russian Federation for 2016-2020"]. Available from: http://government.ru/docs/9529 (in Russian)

14. Kopylov YuA, Jackowska LN, Kudryavtsev MD, Kuzmin VA, Tolstopyatov IA, Iermakov SS. The concept of structure and content of health related trainings for higher educational establishments' students. Physical Education of Students, 2015;5:23-30. http://dx.doi.org/10.15561/20755279.2015.0504

15. Kudriavcev MD, Galimov GIa, Kuz'min VA, Kopylov IuA, Gas'kov AV. Effektivnost' ispol'zovaniia v sisteme fizicheskogo vospitaniia studentov netradicionnykh sredstv na primere khatkha-jogi [Effectiveness of non-traditional means' application in physical education system on example of Hatha yoga]. Vestnik Buriatskogo gosudarstvennogo universiteta, 2014;1:41-44. (in Russian)

16. Kuzmin VA, Kopylov YuA, Kudryavtsev MD, Galimov GY, Iermakov SS. Substantiation of effectiveness of trainings on health related methodic for students with weakened motor fitness. Physical Education of Students, 2015;6:43-49. http://dx.doi.org/10.15561/20755279.2015.0606

17. Lubysheva LI, Bal'sevich VK. Cennosti fizicheskoj kul'tury v zdorovom stile zhizni [Physical culture values in healthy life style]. Mezhdunarodnaia konferenciia "Sovremennye dostizheniia sportivnoj nauki" [International conference "Modern achievements of sports science"], Petersburg; 1994. P. 124-125. (in Russian)

18. Mykhno LS, Loza TO. Effectiveness of yoga-aerobic means' application in physical education of primary school pupils. Pedagogics, psychology, medical-biological problems of physical training and sports, 2016;1:35-40. http://dx.doi.org/10.15561/18189172.2016.0105

19. Najn AIa. Ocenka vliianiia obshcherazvivaiushchikh uprazhnenij na aktivizaciiu poznavatel'noj deiatel'nosti studentov [Assessment of general exercises' influence on activation of students' cognitive functioning]. Teoriia i praktika fizicheskoj kul'tury, 1994;3-4:15-17. (in Russian)

20. Omelyanenko VI. The use of suggestion in sports practice. Pedagogics, psychology, medical-biological problems of physical training and sports, 2013;9:55-58. http://dx.doi.org/10.6084/m9.figshare.751554

21. Rodionov AV, Romanov VA, Iushkov OP. Individualizaciia psikhofizicheskogo treninga pri upravlenii stressovym sostoianiem sportsmenov [Individualization of psycho-physical training in control over sportsmen's stress state]. Mezhdunarodnaia konferenciia "Novye podkhody k psikhoreguliacii v sporte" [International conference "New approaches to psycho-regulation in sports"]. Moscow; 1994.P. 68. (in Russian)

22. Safronov AG. Joga: fiziologiia, psikhosomatika i bioenergetika [Yoga: physiology, psycho-somatic and bioenergetic], Moscow; 2005. (in Russian)

23. Seliutina GV, Diukov VM. Prakticheskaia filosofiia zdorov'ia: koncepty prakticheskoj filosofii zdorov'ia [Practical philosophy of health: concepts of health practical philosophy], LAP LAMBERT Academic Publishing; 2013. (in Russian)

24. Skurikhina N V. Kompleksnaia sistema estestvennogo ozdorovleniia [Complex system of natural healh improvement], Krasnoyarsk: SFU; 2014. (in Russian)

25. Skurikhina NV. Osobennosti proekta "Refleksivno-deiatel'nostnaia pedagogika kak sociokul'turnyj faktor razvitiia fizicheskoj kul'tury v sovremennom obshchestve" [Peculiarities of project "Reflexive-activity pedagogic as social cultural factor of physical culture development in modern society]. XIV mezhdunarodnaia nauchno-prakticheskaia konferenciia "Otechestvennaia nauka v epokhu izmenenij: postulaty proshlogo i teorii novogo vremeni" [14th international scientific practical conference "Domestic science in era of changes: postulates of the past and theories of new time"], Ekaterinburg; 2015. (in Russian)

26. Skurikhina NV, Diukov VM. Fitnes-joga kak effektivnoe sredstvo vliianiia na sostoianie zdorov'ia studentov special'nykh medicinskikh grupp [Fitness yoga as effective mean of influence on special health group students' health]. Sovremennye naukoemkie tekhnologii, 2010;7:115-118. (in Russian)

27. Skurikhina NV, Diukov VM. Primenenie fitnes-jogi dlia povysheniia effektivnosti zaniatij po fizicheskoj kul'ture v VUZe [Application of fitness yoga for increase of effectiveness of HEE physical culture classes]. Sovremennye naukoemkie tekhnologii, 2010;10:107-111(in Russian) 
28. Skurikhina NV, Diukov VM. Vnedrenie ozdorovitel'nykh sistem Fitnes-jogi v praktiku psikhofizicheskoj rekreacii so studentami SMG [Implementation of health related fitness yoga systems in physical recreation practice with SHG students]. V mire nauchnykh otkrytij, 2010;5(1):29-32. (in Russian)

29. Tolcheva AV. Assessment of psycho-physiological state of students with the experience of hatha yoga. Pedagogics, Psychology, Medical-Biological Problems of Physical Training and Sports, 2011;11:128-131.

30. Shvec NN. Joga. Teoriia i praktika [Yoga. Theory and practice], Moscow: Tsyentrpoligraf; 2010. (in Russian)

31. Berger BG, Owen DR. Stress reduction and mood enhancement in four exercise modes: swimming, body conditioning, Hatha yoga and fencing. Research Quarterly for Exercise and Sport, 1988;59:148-159.

32. Bosscher RJ. Running and mixed physical exercises with depressed psychiatric patients. Intern. J. Sport Psychol. 1993,24:170-184. -

33. Qja P. Descriptive epidemiology of health-related physical activity and fitness. Physical Activity, Health and Well-Being, 1995;1:34-39.

34. Rejeski WJ, Thompson A. Historical and Conceptual Roots of Exercise Psychology. In: (Ed. by P.Seraganian) Exerc. Psychology: The Influence of Physical Exerc. on Psychological Processes. Concordia Univ.: A Wiley-Intersci. Publ.: 1993. P. 3-35.

35. Salazar W, Petruzzello S, Landers D, Etnier J, Kubitz K. Meta-analytic techniques in exercise psychology. Ibid., 1998;1:122-145.

36. Weyerer S, Kupfer B. Physical Exercise and Psychological Health. Sports Med., 1994;17(2):108-116. 


\section{Information about the authors:}

Skurikhina N.V.; http://orcid.org/0000-0003-0653-4313; SN397@yandex.ru; Siberian Federal University; 79 Svobodny pr., Krasnoyarsk, 660041, Russia.

Kudryavtsev M.D.; http://orcid.org/0000-0002-4377-0879; kumid@yandex.ru; Siberian Federal University, Siberian State Aerospace University ; 79 Svobodny pr., Krasnoyarsk, 660041, Russia.

Kuzmin V.A.; http://orcid.org/0000-0002-4190-1628; atosn35@mail.ru; Siberian Federal University, Siberian State Aerospace University ; 79 Svobodny pr., Krasnoyarsk, 660041, Russia.

lermakov S.S.; http://orcid.org/0000-0002-5039-4517; sportart@gmail.com; Belgorod National Research University; 85 Pobedy Street, Belgorod, 308015, Russia.

Cite this article as: Skurikhina N.V., Kudryavtsev M.D., Kuzmin V.A., Iermakov S.S. Fitness yoga as modern technology of special health groups' girl students' psychophysical condition and psycho-social health strengthening. Physical education of students, 2016;2:24-31. doi: $10.15561 / 20755279.2016 .0204$

The electronic version of this article is the complete one and can be found online at: http://www.sportpedu.org.ua/html/arhive-e.html

This is an Open Access article distributed under the terms of the Creative Commons Attribution License, which permits unrestricted use, distribution, and reproduction in any medium, provided the original work is properly cited (http://creativecommons.org/licenses/by/4.0/deed.en).

Received: 03.03.2016

Accepted: 19.03.2016; Published: 25.04.2016 